\title{
PENINGKATAN KEMAMPUAN GURU DALAM \\ PENGELOLAAN PEMBELAJARAN TEMATIK SAINTIFIK MELALUI \\ SUPERVISI KLINIS PENDEKATAN HUMANISTIK TEKNIK IMPLANT \\ BAGI GURU KELAS IV DABIN I GUGUS "SUKARNO-HATTA" \\ DINAS PENDIDIKAN KECAMATAN GABUS \\ KABUPATEN PATI PADA SEMESTER I \\ TAHUN PELAJARAN 2014/2015
}

\author{
Kadis \\ Kadispng21@yahoo.com \\ Pengawas Dinas Pendidikan Kecamatan Gabus-Pati
}

\begin{abstract}
The purpose of this research isincreasing the teacher ability in clas IV for distric I group "Soekarno Hatta" Dinas Pendidikan Kecamatan Gabus on semester I of education years 2014/2015 in managing scientifick themes of teaching process in the class through clinic supervison using humanistics implan technic approach.

This research do on the subject all the teacher of grade IV for distric I group "Soekarno Hatta" Dinas pendidikan kecamatan Gabus on semester 1of education years 2014/2015. The methode of this research is School Action Reserach.this action research consist two cycles.the first cycle is clinical supervision with group humanistic implant technich approach, and the second cycle is clinical supervision with individual humanistic implant technich approach. The methode of this research for collecting data is using non test technic. The instruments of this reserach uses observasion and assesment. Validation data is using trianggulasi source involve friends, head school and the subject. Data analysis is deskriptif analysis and continue with reflection. The result of this school research through clinical supervison application with humanistic implant technich, the teacher competency in make scientifick theme indistric 1 group "Soekarno-Hatta" there is signifanct increase that from the first observation $53,13 \%$ cycle I $74,09 \%$, Cycle II $88,28 \%$. The teacher ability in the scientifict themes teaching process from the first observation $52,08 \%$, cycle I $77,96 \%$ cycle II $85,42 \%$. The teacher competency in assesment process in scientifict themes in district I group "Sukarno-Hatta" there was significant increase from the first observation 50,96\%, cycle I $77,01 \%$, cycle II $86,78 \%$. The decide of this research that teacher competency in make RPP scientifik themes in district I group "Sukarno-Hatta" happen the significant increase from the first observation 53,13\%, cycle $174,09 \%$, cycle II 88,28\%. According to theoritical and empiric can be increased, so suoervisor need to do the same research for teacher in their group, for increasing the cappabilty and professioanality of teacher.
\end{abstract}

Keys Word : The teacher's ability in teacher managing of scientfic theme, Clinic supervisi with use Humanistic Implan Technic Approach. 


\section{ABSTRAK}

Tujuan penelitian ini adalah untuk meningkatkan kemampuan guru kelas IV seDabin I Gugus "Sukarno-Hatta" Dinas Pendidikan Kecamatan Gabus pada semester I tahun pelajaran 2014/2015 dalam pengelolaan pembelajaran Tematik Saintifik di kelasnya melalui supervisi klinis dengan menggunakan pendekatan Humanistik teknik Implant. Penelitian ini dilakukan pada subjek penelitian semua guru kelas IV se-Dabin I Gugus "Sukarno-Hatta" Dinas Pendidikan Kecamatan Gabus pada semester I tahun pelajaran 2014/2015. Metode yang digunakan dalam penelitian ini adalah penelitian tindakan sekolah. Action Risearch ini terdiri dari dua siklus, siklus satu merupakan supervisi klinis dengan menggunakan pendekatan Humanistik teknik Implant kelompok, sedangkan siklus dua supervisi klinis dengan menggunakan pendekatan Humanistik teknik Implant individu. Teknik pengumpulan data yang digunakan adalah teknik non tes. Instrument yang digunakan adalah lembar pengamatan dan penilaian. Validasi data menggunakan trianggulasi sumber yang melibatkan teman sejawat, kepala sekolah dan subjek penelitian itu sendiri. Analisis data yang digunakan adalah deskriptif analisis yang dilanjutkan refleksi. Hasil penelitian sekolah ini adalah melalui penerapan supervisi klinis dengan menggunakan pendekatan Humanistik teknik Implant, kompetensi guru dalam penyususnan RPP tematik saintifik di Dabin I Gugus "Sukarno-Hatta" terjadi peningkatan yang signifikan yaitu dari pengamatan awal $53,13 \%$, siklus I 74,09\%, siklus II 88,28\%. Kompetensi guru dalam pelaksanaan pembelajaran tematik saintifik di Dabin I Gugus "Sukarno-Hatta" terjadi peningkatan yang signifikan yaitu dari pengamatan awal 52,08\%, siklus I 77,96\%, siklus II 85,42\%. Kompetensi guru dalam melaksanakan penilaian dalam pembelajaran tematik saintifik di Dabin I Gugus "Sukarno-Hatta" terjadi peningkatan yang signifikan yaitu dari pengamatan awal 50,96\%, siklus I 77,01\%, siklus II 86,78\%. Dalam penelitian ini disimpulkan bahwa Kompetensi guru dalam penyususnan RPP tematik saintifik di Dabin I Gugus "Sukarno-Hatta" terjadi peningkatan yang signifikan yaitu dari pengamatan awal 53,13\%, siklus I $74,09 \%$, siklus II $88,28 \%$. Karena secara teori dan empirik dapat meningkat, maka pengawas perlu melakukan penelitian-penelitian sejenis bagi guru-guru di daerah binaannya, guna meningkatkan kemampuan dan profesional guru.

Kata kunci : Pembelajaran Tematik Saintifik, Supervisi Klinis Pendekatan Humanistik Teknik Implant

\section{PENDAHULUAN}

Kemampuan guru dalam pengelolaan pembelajaran di kelas merupakan salah satu dari tuntutan profesi yang harus terpenuhi, dalam rangka mewujudkan predikat guru profesional. Muara dari profesionalitas guru dalam pengelolaan pembelajaran adalah peningkatan mutu sekolah dan mutu pembelajaran pada umumnya. Pembelajaran yang diamanatkan dalam Kurikulum 2013, menekankan pada dimensi pedagogik modern dalam pembelajaran, yaitu menggunakan 
pendekatan ilmiah. Pendekatan ilmiah (scientific approach) dalam pembelajaran sebagaimana dimaksud meliputi mengamati, menanya, mengumpulkan informasi dan mencoba, mengasosiasikan dan menalar, dan menyajikan dan mengkomunikasikan hasil untuk semua mata pelajaran dengan menggunakan pendekatan tematik (Tematik Saintifik). Untuk materi, atau situasi tertentu, sangat mungkin pendekatan ilmiah ini tidak selalu tepat diaplikasikan secara prosedural. Pada kondisi seperti ini, tentu saja proses pembelajaran harus tetap menerapkan nilai-nilai atau sifat-sifat ilmiah dan menghindari nilai-nilai atau sifat-sifat non ilmiah. Tututan inilah yang harus dipenuhi guru dalam pengelolaan pembelajaran yang meliputi perencanaan, pelaksanaan dan penilaian pembelajaran.

Kenyataan yang terjadi di wilayah binaan peneliti, yaitu di Dabin I Gugus "Sukarno-Hatta" pada semester I Tahun 2014/2015, guru-guru kelas IV dalam mengelola pembelajaran Tematik Saintifik, yang meliputi penyusunan RPP, pengelolaan pembelajaran dan pengelolaan penilaian, belum dilaksanakan secara maksimal. Hal ini terlihat pada hasil analisis pengamatan awal pengelolaan pembelajaran Tematik Saintifik sebagai berikut; dari 8 guru, penyusunan RPP dalam kategori sedang $(59,64 \%)$, pengelolaan pembelajaran Tematik Saintifik dalam kategori sedang $(60,42 \%)$, pengelolaan penilaian dalam kategori sedang $(58,65 \%)$. Hal tersebut juga didukung fakta penilaian EDS maupun Akreditasi Sekolah khususnya dalam komponen standar proses rata-rata belum ada yang dalam kategori tinggi (61\%-80\%) atau dalam kategori amat tinggi (81\%-100\%).

Faktor penyebabnya antara lain : rendahnya pemahaman guru tentang pengelolaan pembelajaran Tematik Saintifik, keberadaan dan keragaman kemampuan guru kelas IV dalam mengelola pembelajaran Tematik Saintifik, kurangnya sarana prasarana pendukung termasuk buku Tematik Saintifik. Permasalahan yang dihadapi oleh guru kelas IV, salah satunya adalah kompetensi guru yang masih relatif rendah dalam pengelolaan Tematik Saintifik. Ditambah pula dengan belum adanya pembinaan yang berorientasi pada kebutuhan guru dalam mengembangkan kemampuan profesional dalam pelaksanaan pembelajaran Tematik Saintifik. Peran pengawas sekolah selaku pemantau, pembina dan penilai di daerah yang menjadi tanggung jawab pengawasannya, belum maksimal dalam 
melaksanakan supervisi akademik untuk membantu guru dalam pengelolaan pembelajaran Tematik Saintifik.

Kemampuan guru dalam pengelolaan pembelajaran Tematik Saintifik ini akan ditingkatkan melalui supervisi klinis dengan menggunakan pendekatan Humanistik teknik Implant bagi guru kelas IV akademik dengan pendekatan kolaboratif bagi guru ke Dabin I Gugus "Sukarno-Hatta" Dinas Pendidikan Kecamatan Gabus Kabupaten Pati pada semester I Tahun 2014/2015

Pembelajaran tematik dilaksanakan dengan menggunakan prinsip pembelajaran terpadu. Pembelajaran terpadu melalui tema sebagai pemersatu kegiatan yang memadukan beberapa mata pelajaran sekaligus dalam satu kali tatap muka, dimaksudkan untuk memberikan pengalaman yang bermakna kepada siswa. Karena siswa dalam memahami berbagai konsep yang mereka pelajari selalu melalui pengalaman langsung dan menghubungkannya dengan konsep lain yang telah dikuasainya. Ide tentang pembelajaran tematik berawal dari kenyataan bahwa salah satu unsur penentu ketercapaian hasil belajar dan suatu sistem pendidikan adalah proses pembelajaran.

Humanistik adalah pandangan menekankan bahwa individu adalah penentu bagi tingkah laku dan pengalamannya sendiri, sebagai agen yang sadar, bebas memilih atau menentukan sistematik tindakannya (Megawangi dalam Maslow, 2005:87). Humanistik menampilkan gambaran manusia sebagai mahkluk yang bebas dan bermartabat serta selalu bergerak kearah pengungkapan segenap potensi yang dimilikinya apabila lingkungan memungkinkan.

IMPLANT adalah teknik memasukkan sesuatu kepada seseorang dengan menanamkan di dalam sistem metabolisme tubuh yang berguna untuk mengatur sistem metabolisme tubuh manusia (Widianing, 2009:37). Sedangkan menurut Zhong Zhang (2008:42), teknik implant dapat dilakukan dengan menggunakan metode "susuk" di dawah kulit yang akan bekerja secara efektif sesuai dengan daya penerimaan tubuh. Secara sederhana teknik implant dalam pelaksanaan supervisi dapat dipahami sebagai "usaha mestimuli, mengkoordinasi dan membimbing secara kontinyu pertumbuhan guru-guru di sekolah, baik secara 
individual maupun secara kolektif, agar para guru lebih mengerti dan lebih efektif dalam mewujudkan seluruh fungsi pengajaran" (Sahertian, 2000:17). Lebih lanjut Sukmanto (2011:19) menjelaskan bahwa "kata kunci" dari teknik implant ialah memberikan layanan dan bantuan kepada guru-guru, maka tujuan supervisi teknik implant adalah memberikan layanan dan bantuan untuk mengembangkan situasi belajar-mengajar yang dilakukan guru di kelas". Dalam penelitian ini teknik Implant terdiri dari kegiatan : 1) identifity yaitu mengidentifikasi permasalahan merupakan kegiatan terencana yang ditujukan pada aspek kualitatif yang dilakukan bersama anatara guru dan pengawas secara kolaboratif. 2) magnificent adalah kegiatan memberikan penghargaan (reward) kepada guru atas peran sertanya untuk menemukan permasalahan dirinya secara obyektif apa adanya. 3) planing bertujuan untuk merancang pengelolaan pembelajaran yang dapat membelajarkan siswa, bagaimana membuat siswa berpartisipasi aktif dalam proses pembelajaran. 4) action dimaksudkan untuk menerapkan desain atau perencanaan yang telah dirumuskan oleh guru secara kolaboratif. 5) negotiate yaitu mengorganisasi data pengamatan ke dalam bidang kualitatif yang jelas untuk umpan balik pada guru. 6) Treaty. yang berarti perjanjian antara pengawas dengan guru untuk menjaga dan meningkatkan profesionalisme atau kompetensi guru dalam pengelolaan pembelajaran. Dalam tahapan ini, pengawas perlu membuat daftar kendali yang merupakan instrumen untuk mempertimbangkan dan mengevaluasi situasi nyata dari suatu aktivitas/situasi yang terjadi didalam kelas setelah pelaksanaan supervisi klinis. 


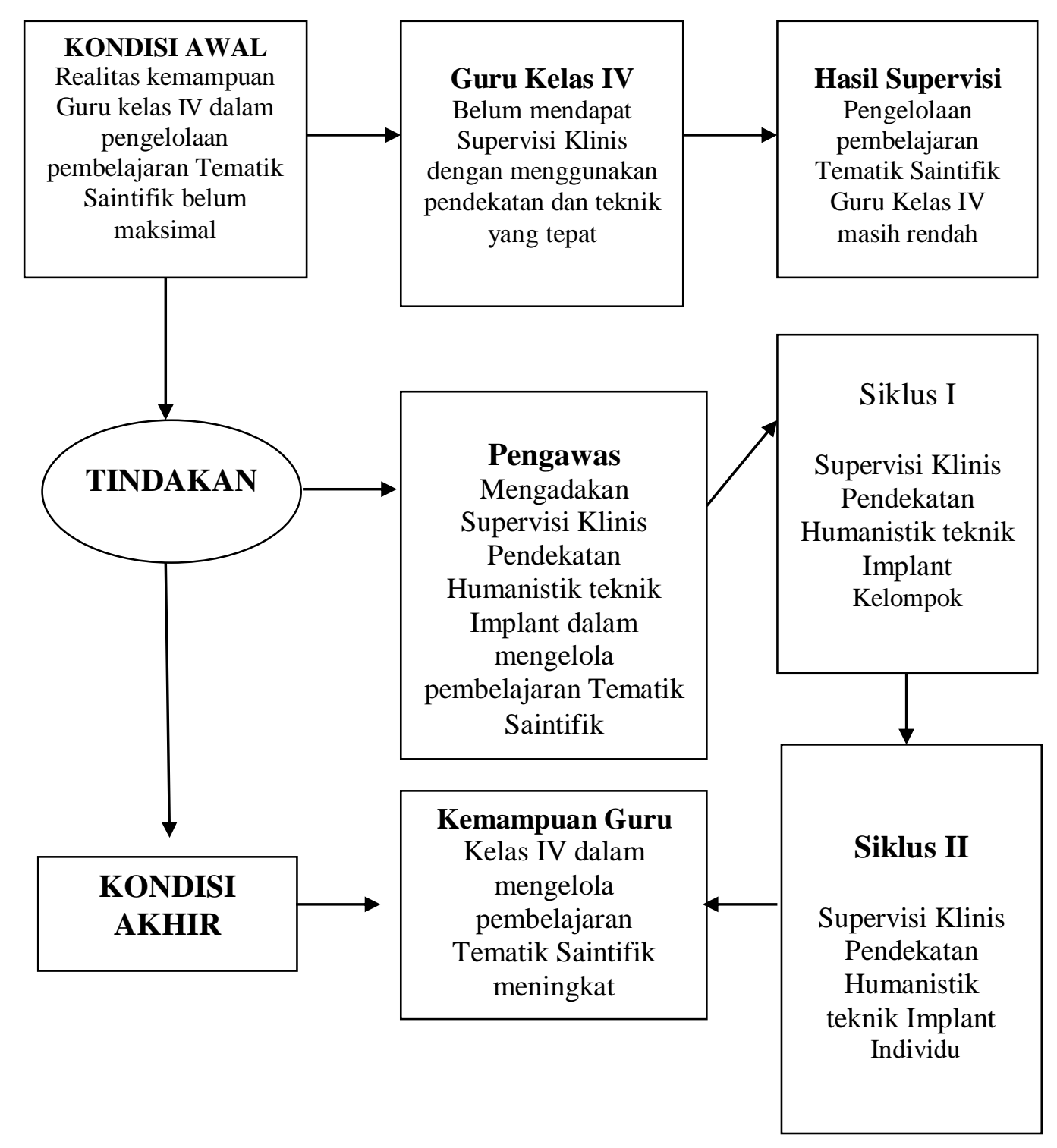

\section{Gambar}

\section{Kerangka Berpikir}

\section{METODE PENELITIAN TINDAKAN}

Penelitian ini dilakukan dengan menggunakan metode Penelitian Tindakan sekolah (PTS) yang terdiri dari 2 siklus. Langkah-langkah tiap siklus terdiri dari Planning, Acting, Observing, Reflecting 


\section{Siklus I}

\section{Perencanaan (Planning)}

Dalam langkah perencanaan Penelitian Tindakan Sekolah tahap Planning ini disiapkan hal-hal sebagai berikut : (a) menyiapkan bahan, inventarisasi kebutuhan, dan inventarisasi masalah, (b) Berdiskusi dengan guru tentang hal-hal yang dapat dilakukan untuk peningkatan kemampuan pengelolaan pembelajaran Tematik Saintifik, (c) menyiapkan jadwal pelaksanaan pendampingan, (d) menyiapkan bahan dan alat yang dibutuhkan dalam pendampingan.

Dalam langkah peneliti ini, dilaksanakan tahapan supervisi klinis pendekatan humanistik teknik Implant yang meliputi :

1. Tahap Identifity, yang meliputi kegiatan:

a) Mendengarkan dengan sabar tentang deskripsi keberhasilan pengelolaan pembelajaran Tematik Saintifik yang telah dilakukan oleh guru.

b) Mendengarkan dengan sabar tentang deskripsi kekurangan pengelolaan pembelajaran Tematik Saintifik yang telah dialami oleh guru.

c) Menawarkan insentif atau dorongan untuk mencari akar masalah dengan tepat.

d) Mempertimbangkan reaksi dan pemahaman guru dengan tepat.

e) Menjelaskan, merangsang (stimulating) dan memuji secara simpatik dan penuh perhatian.

2. Tahap Magnificent, yang meliputi kegiatan:

a) Menunjukkan secara objektif temuan yang diperoleh selama proses belajar-mengajar, sehingga terjadi kesepahaman antara guru dan supervisor tentang hal-hal yang perlu diperbaikan dan yang perlu dikembangkan.

b) Mereview catatan proses dan hasil dengan menggunakan parameter keberhasilan sebagai telah disepakati dalam pertemuan pendahuluan.

c) Selanjutnya supervisor memberikan penguatan berupa dukungan, pujian, atau pengakuan bahwa proses pembelajaran yang diobservasi merupakan implementasi yang telah dilaksanakan secara bersungguh-sungguh. 
3. Tahap Planning, yang meliputi kegiatan:

a) Menganalisis permasalahan yang dihadapi dalam pembelajaran, dalam hal ini pembelajaran tematik saintifik di kelas IV

b) Merancang pengelolaan pembelajaran dalam bentuk RPP pembelajaran Tematik Saintifik, yang dapat membelajarkan siswa secara aktif dan efektif.

c) Ujicoba rancangan pengelolaan pembelajaran Tematik Saintifik.

\section{Pelaksanaan Tindakan (action)}

Dalam langkah pelaksanaan Penelitian Tindakan Sekolah tahap action ini dilakukan kegiatan action sesuai dengan supervisi klinis pendekatan humanistik teknik implan sebagai berikut :

1. Pendampingan dari pengawas terhadap guru kelas IV dalam mempersiapkan administrasi program pengelolaan pembelajaran Tematik Saintifik berupa prota, promes, silabus dan RPP.

2. Pendampingan dilakukan pengawas terhadap guru kelas IV yang kesulitan dalam memenuhi kelengkapan administrasi pembelajaran khususnya dalam penyusunan RPP Tematik Saintifik terutama dalam kegiatan yang lebih rinci.

3. Pengawas membantu menyiapkan bukti fisik yang diperlukan.

4. Pengawas berperan selaku pembimbing dalam penyusunan administrasi program pembelajaran.

5. Pengawas mendampingi dan menilai pelaksanaan pengelolaan pembelajaran Tematik Saintifik sesuai dengan program pembelajaran yang telah tersusun.

\section{Pengamatan (Observation)}

Dalam langkah Pelaksanaan Tindakan PTS tahap observation ini dilakukan tindakan supervisi klinis pendekatan humanistik teknik implant berupa tahapan dengan fokus pengamatan oleh pengawas dan kolaborator sebagai berikut: 
1. Konsistensi guru dalam berperan aktif selama pembelajaran Tematik Saintifik berlangsung.

2. Kemampuan guru dalam melibatkan siswa pada proses pembelajaran Tematik Saintifik.

3. Kemampuan guru dalam menggunakan alat pelajaran (alat peraga).

4. Efektifitas guru dalam penerapan model dan metode pembelajaran.

5. Kemampuan guru dalam memilih alat bantu pembelajaran yang relevan dengan materi ajar.

6. Kemampuan guru dalam menampilkan pembelajaran nyata di dalam kelas. Pengamatan dilakukan pada setiap tahap penelitian, mulai dari tahap perencanaan dan pelaksanaan tindakan, kejadian dan hal-hal yang terjadi direkam dalam bentuk catatan. Catatan hasil observasi, dan didokumentasikan sebagai data-data penelitian.

\section{Refleksi (Reflection)}

Dalam tahap pelaksanaan PTS ini dilakukan kegiatan supervisi klinis pendekatan humanistik teknik implant sebagai berikut:

\section{Negotiate}

Dalam tahapan negotiate ini kegiatan yang dilakukan pengawas adalah sebagai berikut:

a) Mengorganisasi data pengamatan ke dalam bidang kualitatif yang jelas untuk umpan balik pada guru.

b) Pengawas bersama kolaborator kemudian membuat analisis yang menyeluruh/komprehensif pada data yang ada untuk menafsirkan hasil pengamatannya.

c) Bersama guru mengidentifikasi perilaku pembelajaran yang positif, yang harus dipelihara dan perilaku negatif yang harus dirubah, agar dapat menyelesaikan/menanggulangi masalah.

d) Membat kesepakatan bersama kolaborator tentang perilaku positif pembelajaran yang harus dipelihara, strategi-strategi alternatif untuk mencapai perubahan yang diinginkan. Dan 
kelayakan/kepantasan dari menggunakan kembali metode yang pernah dilakukan.

\section{Treaty}

Dalam tahapan Treaty ini kegiatan yang dilakukan pengawas adalah sebagai berikut:

a) Menunjukkan secara objektif temuan yang diperoleh selama proses belajar-mengajar, sehingga terjadi kesepahaman antara guru dan supervisor tentang hal-hal yang perlu diperbaikan dan yang perlu dikembangkan.

b) Mereview catatan proses dan hasil dengan menggunakan parameter keberhasilan yang telah disepakati dalam pertemuan pendahuluan.

c) Bersama guru membuat kesepakatan yang berupa perjanjian, apabila di suatu saat guru mengalami masalah dalam pengelolaan pembelajaran, atau masalah-masalah lainnya dalam upaya meningkatkan mutu pembelajaran.

\section{Siklus II}

Kegiatan tindakan pada siklus II didasarkan pada temuan-temuan di siklus I, adapun langkah-langkah tindakan yang dilakukan sama dengan pada siklus I.

\section{HASIL TINDAKAN DAN PEMBAHASAN}

Setelah melakukan penelitian tentang peningkatan kemampuan guru dalam pengelolaan pembelajaran tematik saintifik melalaui supervisi klinis pendekatan humanistik teknik implant pada siklus II, berikut ini akan disajikan perbandingan hasil penelitian siklus awal, siklus I, dan siklus II pada peningkatan kemampuan guru dalam pengelolaan pembelajaran tematik saintifik melalaui supervisi klinis pendekatan humanistik teknik implant Dabin I Gugus "Sukarno-Hatta" Dinas Pendidikan Kecamatan Gabus. Perbandingan yang akan disajikan yaitu tentang hasil penelitian berupa kemampuan guru dalam penyusunan RPP, pelaksanaan pembelajaran tematik saintifik, penilaian pembelajaran tematik saintifik, pelaksanaan supervisi dan tanggapan guru sebagai berikut : 
Perbandingan Kondisi Awal, Siklus I, dan Siklus II

\begin{tabular}{|c|c|c|c|c|}
\hline No & Uraian & Kondisi Awal & Siklus I & Siklus II \\
\hline 1 & Kegiatan & $\begin{array}{l}\text { Belum diterapkan } \\
\text { supervisi klinis } \\
\text { pendekatan } \\
\text { humanistik teknik } \\
\text { implant }\end{array}$ & $\begin{array}{l}\text { Sudah menerapkan } \\
\text { supervisi klinis } \\
\text { pendekatan } \\
\text { humanistik teknik } \\
\text { implant }\end{array}$ & $\begin{array}{l}\text { Sudah menerapkan } \\
\text { supervisi klinis } \\
\text { pendekatan } \\
\text { humanistik teknik } \\
\text { implant }\end{array}$ \\
\hline 2 & $\begin{array}{l}\text { Kemampuan } \\
\text { guru menyusun } \\
\text { RPP }\end{array}$ & $\begin{array}{l}\text { Nilai terendah } 44,79 \\
\text { Nilai tertinggi } 63,54 \\
\text { Nilai rerata } 53,13\end{array}$ & $\begin{array}{l}\text { Nilai terendah } 59,40 \\
\text { Nilai tertinggi } 82,30 \\
\text { Nilai rerata } 74,09\end{array}$ & $\begin{array}{l}\text { Nilai terendah } 82,3 \\
\text { Nilai tertinggi } 92,7 \\
\text { Nilai rerata } 88,28\end{array}$ \\
\hline 3 & $\begin{array}{l}\text { Kemampuan } \\
\text { guru } \\
\text { melaksanakan } \\
\text { pembelajaran }\end{array}$ & $\begin{array}{l}\text { Nilai terendah } 36,10 \\
\text { Nilai tertinggi } 65,30 \\
\text { Nilai rerata } 52,08\end{array}$ & $\begin{array}{l}\text { Nilai terendah } 65,30 \\
\text { Nilai tertinggi } 84,70 \\
\text { Nilai rerata } 77,96\end{array}$ & $\begin{array}{l}\text { Nilai terendah } 81,9 \\
\text { Nilai tertinggi } 91,7 \\
\text { Nilai rerata } 85,42\end{array}$ \\
\hline 4 & $\begin{array}{l}\text { Kemampuan } \\
\text { guru melakukan } \\
\text { penilaian }\end{array}$ & $\begin{array}{l}\text { Nilai terendah } 32,70 \\
\text { Nilai tertinggi } 69,2 \\
\text { Nilai rerata } 50,96\end{array}$ & $\begin{array}{l}\text { Nilai terendah } 63,50 \\
\text { Nilai tertinggi } 84,90 \\
\text { Nilai rerata } 77,01\end{array}$ & $\begin{array}{l}\text { Nilai terendah } 80,8 \\
\text { Nilai tertinggi } 92,3 \\
\text { Nilai rerata } 86,78\end{array}$ \\
\hline 5 & $\begin{array}{l}\text { Pelaksanaan } \\
\text { supervisi klinis } \\
\text { humanistik } \\
\text { teknik implant }\end{array}$ & 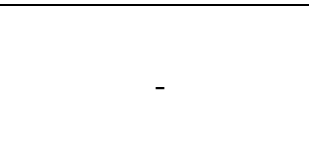 & $\begin{array}{l}\text { Nilai terendah } 64,30 \\
\text { Nilai tertinggi } 83,90 \\
\text { Nilai rerata } 77,01\end{array}$ & $\begin{array}{l}\text { Nilai terendah } 81,3 \\
\text { Nilai tertinggi } 92,9 \\
\text { Nilai rerata } 86,5\end{array}$ \\
\hline 6 & $\begin{array}{l}\text { Tanggapan guru } \\
\text { tentang } \\
\text { pelaksanaan } \\
\text { supervisi }\end{array}$ & - & $\begin{array}{l}\text { Nilai terendah } 70 \\
\text { Nilai tertinggi } 85 \\
\text { Nilai rerata } 79,38\end{array}$ & $\begin{array}{l}\text { Nilai terendah } 85 \\
\text { Nilai tertinggi } 95 \\
\text { Nilai rerata } 89,69\end{array}$ \\
\hline
\end{tabular}

Dari data perbandingan hasil penelitian pada siklus awal, siklus I, dan hasil penelitian pada siklus II di atas disajikan dalam bentuk diagram sebagai berikut:

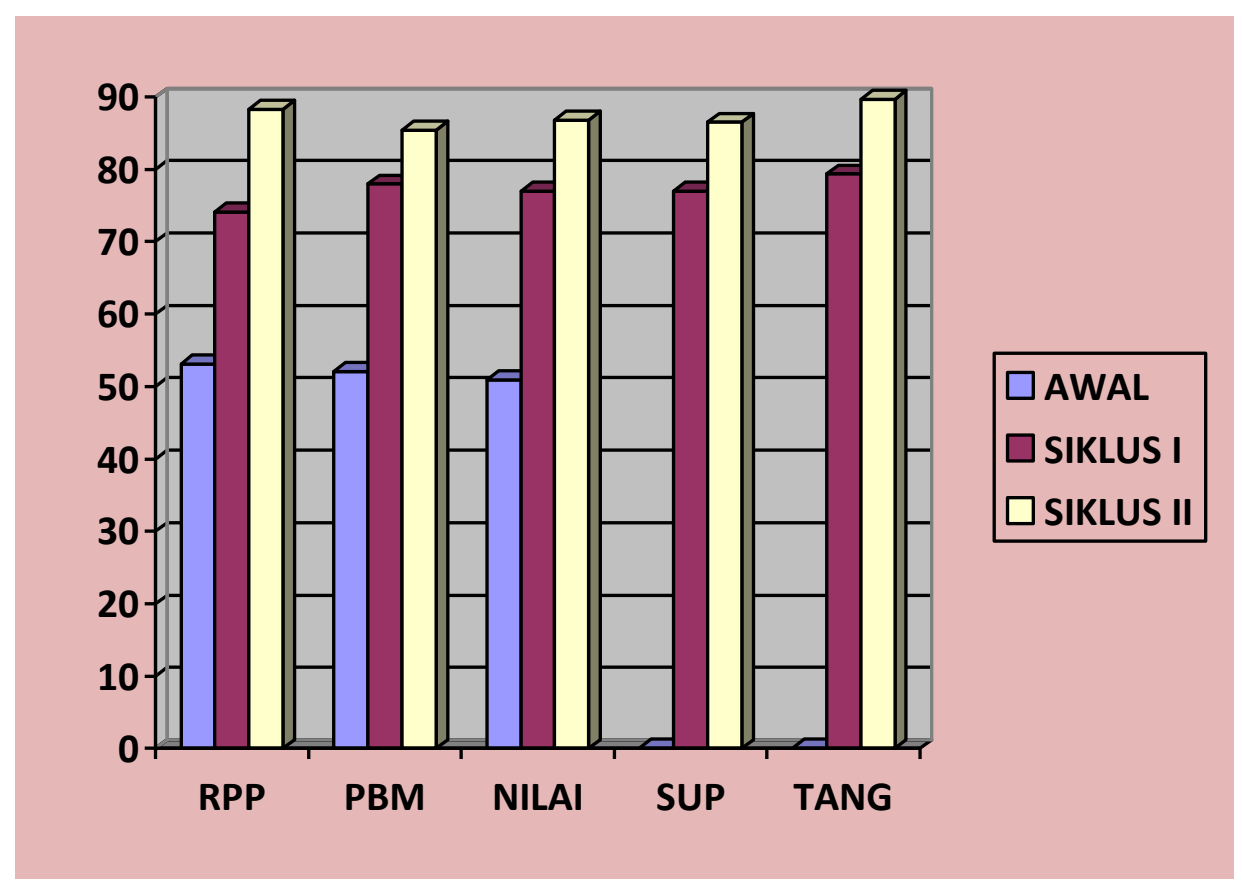

Perbandingan Kondisi Awal, Siklus I dan Siklus II 
Deskriptif komparatif dari kondisi awal dengan kondisi Siklus I dan Silus II pada penelitian ini adalah dalam kegiatan penelitian kondisi awal belum diterapkan supervisi klinis pendekatan humanistik teknik implant. Dibandingkan pada siklus awal dengan siklus II setelah supervisi klinis pendekatan humanistik teknik implant, diperoleh dari kemampuan guru dalam penyusunan RPP Tematik Saintifik dengan peningkatan rerata 36,20\%, yaitu dari 52,08 menjadi 88,28. Kemapuan guru dalam pelaksanaan pembelajaran tematik saintifik terjadi peningkatan rerata $33,34 \%$, yaitu dari 52,08 menjadi 85,42 . Sedangkan untuk kemampuan guru dalam penilaian pembelajaran tematik saintifik juga terjadi peningkatan rerata sebesar 35,82\%, yaitu dari 50,96 menjadi 86,78. Sedangkan data hasil penelitian pada pelaksanaan supervisi klinis humanistik teknik implant pada siklus II terjadi peningkatan bila dibandingkan pada siklus I yaitu 9,49\%, dari 77,01 menjadi 86,5. Sedangkan tanggapan guru tentang pelaksanaan supervisi klinis humanistik teknik implant pada siklus I dan Siklus II terjadi peningkatan yaitu $10,31 \%$, dari 79,38 menjadi 89,69.

Dari data hasil penelitian di atas dapat disimpulkan bahwa ada peningkatan kemampuan guru yang signifikan dalam pengelolaan pembelajaran tematik saintifik setelah diterapkan supervisi klinis pendekatan humanistik teknik implant pada siklus II.

Peningkatan kemampuan pengelolaan pembelajaran tematik saintifik pada siklus II secara rerata sudah cukup optimal, yaitu sudah mencapai skor amat baik. Maka berdasarkan data penelitian tersebut tindakan supervisi klinis pendekatan humanistik teknik implant dinyatakan telah memenuhi hasil yang diharapkan. Berdasarkan hasil supervisi klinis humanistik teknik implant perlu diterapkan supervisi klinis pendekatan humanistik teknik implant pada guru dan kelas lain.

\section{PENUTUP}

\section{A. Simpulan}

Dari hasil penelitian di atas dapat ditarik kesimpulan bahwa terjadi peningkatan yang signifikan pada kemampuan guru kelas IV di Dabin I gugus "Sukarno-Hatta" Dinas Pendidikan Kecamatan Gabus Tahun ajaran 2014/2015 
semester I dalam pengelolaan pembelajaran tematik saintifik setelah dilakukan supervisi klinis pendekatan humanistik teknik implant

Atas dasar kajian teoritik dan pengujian empirik di atas, maka dapat disimpulkan bahwa melalui penerapan supervisi klinis pendekatan humanistik teknik implant dapat meningkatkan kemampuan guru kelas IV di Dabin I gugus "Sukarno-Hatta" Dinas Pendidikan Kecamatan Gabus Tahun ajaran 2014/2015 semester I dalam pengelolaan pembelajaran tematik saintifik.

Proses pengaplikasian supervisi klinis pendekatan humanistik teknik implant yang diterapkan baik dalam siklus I maupun siklus II, melalui kolaborasi dengan teman sejawat, dan kepala sekolah dalam supervisi supervisi klinis pendekatan humanistik teknik implant mampu meningkatkan kemampuan guru kelas IV di Dabin I gugus "Sukarno-Hatta” Dinas Pendidikan Kecamatan Gabus Tahun ajaran 2014/2015 semester I dalam pengelolaan pembelajaran tematik saintifik secara signifikan. Hal tersebut dibuktikan dengan terjawabnya masalah dan tercapainya tujuan pada bab I yaitu: Kompetensi guru dalam penyususnan RPP tematik saintifik di Dabin I Gugus "Sukarno-Hatta" terjadi peningkatan yang signifikan yaitu dari pengamatan awal 53,13 \%, siklus I 74,09\%, siklus II 88,28\%. Kompetensi guru dalam pelaksanaan pembelajaran tematik saintifik di Dabin I Gugus "Sukarno-Hatta" terjadi peningkatan yang signifikan yaitu dari pengamatan awal 52,08\%, siklus I 77,96\%, siklus II 85,42\%. Kompetensi guru dalam melaksanakan penilaian dalam pembelajaran tematik saintifik di Dabin I Gugus "Sukarno-Hatta" terjadi peningkatan yang signifikan yaitu dari pengamatan awal 50,96\%, siklus I 77,01\%, siklus II 86,78\%.

Pelaksanaan Supervisi klinis pendekatan humanistik teknik implant di Gugus "Sukarno-Hatta" terjadi peningkatan yang signifikan yaitu dari pengamatan siklus I 77,01\%, siklus II $86,5 \%$. Tanggapan guru dalam pelaksanaan Supervisi klinis pendekatan humanistik teknik implant di Gugus "Sukarno-Hatta" terjadi peningkatan yang signifikan yaitu dari pengamatan siklus I 79,38\%, siklus II 89,69\%. Yang berarti hasil akhir dalam kategori amat baik. 


\section{B. Implikasi}

Karena secara teori dan empirik dapat meningkat, maka pengawas perlu melakukan penelitian-penelitian sejenis bagi guru-guru di daerah binaannya, guna meningkatkan kemampuan dan profesional guru dalam menghadapi sertifikasi guru, pengusulan PAK, pelaksanaan EDS maupun akreditasi sekolah. Penelitian ini juga dapat meningkatkan kompetensi pengawas dalam peningkatan pelaksanaan standar proses serta secara umum dapat meningkatkan mutu pendidikan, serta berguna untuk peningkatan karir serta pelaksanaan tupoksi pengawas.

\section{Saran}

1. Bagi Guru

Hendaknya Guru selalu proaktif terhadap penelitian yang diadakan oleh pengawas, mengingat hasil penelitian juga sangat bermanfaat serta dapat meningkatkan kemampuan dalam pengelolaan pembelajaranTematik saintifik di kelasnya, sesuai dengan yang diamanatkan dalam Kurikulum 2013.

2. Bagi Kepala Sekolah

Hendaknya Kepala Sekolah juga membantu, memfasilitasi dan turut berpartisipasi/berkolaborasi aktif dalam pelaksanaan pembelajaran Tematik Saintifik, serta mengadakan supervisi secara rutin kepada guruguru di sekolahnya.

3. Bagi Sekolah

Sekolah sebagai lembaga melalui dewan guru, Kepala Sekolah, dan Komite sekolah diharapkan melalui kebijakan serta programnya dapat mendukung upaya-upaya pembaharuan pendidikan seperti yang dilakukan saat pada penelitian ini, terutama dalam penerapan pembelajaran tematik saintifik. 


\section{DAFTAR PUSTAKA}

Agus Taufiq. 2009. Supervisi Klinis untuk Perbaikan Pembelajaran. Diterbitkan 1 Maret 2008 kurikulum dan pembelajaran 19 Comments Tags http://akhmadsudrajat.wordpress.com/2008/03/01/supervisi-klinis. (22 Juli 2013)

Arends, Richard I., (2007). Learning to Teach. Seventh Edition, Boston: Mc Graw Hill.

Arifin, CH, 2001. Menggagas Alternatif Model Pembelajaran Efektif. Bandung : CV Diponegoro.

Bergmann. 2007. Opportunity to Learn Thematic Model to Study Science. Faculty of Education, University of Calgary, Calgary, Canada. Vol XII No 21, http://www.google.co.id/org.mozilla\%.springerlink.journal.education.learn ing\&btnG\&meta.cr\%3DcountryID. (12 Juni 2009).

Dahar, Ratna Wilis. 1996. Teori-teori Belajar. Jakarta: Erlangga.

Depdiknas. 2003. Undang-undang Republik Indonesia Nomor 20 Tahun 2003 tentang Sistem Pendidikan Nasional. Jakarta: Diperbanyak oleh Sinar Grafika.

--.2006. Pedoman Pembelajaran Tematis untuk Guru Kelas I, II dan III Sekolah Dasar dan Madrasah Ibtidaiyah. Jakarta : Depdiknas.

-2006. Pedoman Pembelajaran untuk Guru Kelas Sekolah Dasar dan Madrasah Ibtidaiyah. Jakarta : Depdiknas.

Endang Rahayu. 2012. Meningkatkan Kemampuan Guru Dalam Mengelola Pembelajaran Tematik Melalui Supervisi Akademik Pendekatan Kolaboratif Teknik Peer Coaching Bagi Guru Sekolah Dasar. PTS

Gerry Stahl, 2007. Using Activity-Oriented Design Methods to Study Collaborative Knowledge Building in Learning Courses. Journal Contents. DOI. http://ijcscl.org/?go=contents\&volume=2\&issue=4 . ( 22 Juli 2009).

Greene. K. 2003. Professional Development in Early Intervention. Journal and Literacy. http://www.nwrel.org/lessonstudy/resources/\&ei = uux NSt 7AM . (12 Juli 2009).

Hartono. 2007. Pembelajaran Model Tematik untuk Mengatasi Anak Berkesulitan Belajar Calistung di Kelas I SD Negeri 03 Brujul Surakarta. Salatiga. Widya Sari. 
Janette R, dkk. 2001. Teaching and learning in digital environments: The resurgence of resource-based learning, http://www. springerlink. com/ content/ 5w4762x03122k355.(12 Juli 2013).

, (2007). continuing the exploration of opportunities and obstacles.

http://inderscience.metapress.com/app/home/contribution.asp?referrer=par ent\&backto=issue, 2,8;journal,10,15;linkingpublicationresults, 1:112926,1. .(12 Juli 2013).

Louise Moqvist. 2003. The Competency Dimension of Leadership: Findings from a Study of Self-Image among Top Managers in the Changing Swedish Public Administration. Centre for Studies of Humans, Technology and Organisation, Linköping University.

Megawangi, Ratna. 2005. Pendidikan Holistik. Jakarta: Indonesia Heritage Foundation.

Parso.2004. Pengaruh In Servise Training dan Supervisi Kunjungan Kelas Terhadap Kompetensi Profesional Guru SMP Negeri Se Kabupaten Jepara. Thesis. Semarang : Program Pasca Sarjana UNNES

Purwanto N, 2007, Ilmu Pendidikan Teoritis dan Praktis. Bandung : PT. Remaja Rosdakarya

Sahertian, Piet. 2000. Konsep Dasar Teknik Supervisi Pendidikan Dalam Rangka Pengembangan Sumber Daya Manusia. Jakarta: Rineka Cipta.

Sarwono. 2009. Pemanfaatan Lingkungan Sebagai Sumber Belajar di Kelas IV SDN Kleco I Surakarta. Semarang. Widya Tama.

Speroff Leon, 2005. Effective Teaching Strategies Lessons From Research and Practice. Second Edition. Australia: Social Science Press.

Zhong Zhang. 2008. An integrated Classification Method for Thematic Learning. Journal of Zhejiang.University-Science-A.VolXXIII. 